Mixing Musics 
Stanford Studies in Jewish History and Culture edited ву Aron Rodrigue and Steven J. Zipperstein 


\section{Mixing Musics Turkish Jewry and the \\ Urban Landscape of a Sacred Song}

Maureen Jackson

STANFORD UNIVERSITY PRESS STANFORD, CALIFORNIA 
Stanford University Press

Stanford, California

C 2013 by the Board of Trustees of the Leland Stanford Junior University.

All rights reserved.

No part of this book may be reproduced or transmitted in any form or by any means, electronic or mechanical, including photocopying and recording, or in any information storage or retrieval system without the prior written permission of Stanford University Press.

Printed in the United States of America on acid-free, archival-quality paper

Library of Congress Cataloging-in-Publication Data

Jackson, Maureen (Maureen Barbara), author.

Mixing musics : Turkish Jewry and the urban landscape of a sacred song / Maureen Jackson.

pages ; cm.--(Stanford studies in Jewish history and culture)

Originally presented as the author's thesis (doctoral)--University of Washington, 2008.

Includes bibliographical references and index.

ISBN 978-0-8047-8015-5 (cloth : alk. paper)

ISBN 978-0-8047-9726-9 (pbk. : alk. paper)

I. Synagogue music--Turkey--Istanbul--History and criticism. 2. Jews--Turkey-Istanbul--Music--History and criticism. 3. Sacred music--Turkey--Istanbul--2oth century--History and criticism. 4. Sacred music--Turkey--Istanbul--2Ist century-History and criticism. I. Title. II. Series: Stanford studies in Jewish history and culture.

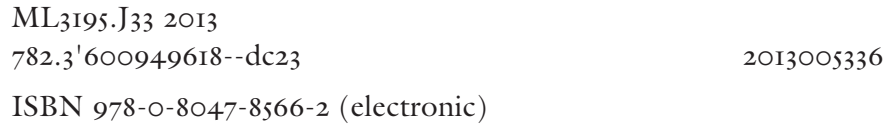

Typeset by Bruce Lundquist in I0.5/I4 Galliard. 
Dedicated to my mother, Barbara Jacksonyour aesthetic sensibility delights and resilience inspires 
